ENGAGING STIGMA:

\title{
AN EMBODIED THEOLOGICAL RESPONSE TO HIV AND AIDS ${ }^{1}$
}

\author{
Denise Ackermann \\ Stellenbosch University
}

\begin{abstract}
This paper explores the nature of stigma in relation to HIV/Aids by way of fifteen interrelated observations. It serves as an example of "embodied theology". It also offers reflections on what could constitute an appropriate response to stigma on the part of communities of faith in order to clarify and strengthen their roles in combating the Aids pandemic.

"Thembi" grew thin, lost her appetite and then became too weak to get out of bed. "I asked my mother to come from the Transkei to nurse me because my boyfriend had gone back to Maputo. I cannot tell my mother that I have the 'new sickness'. She thought I had been 'toored' (bewitched) and sent for the sangoma (healer) to rub me with herbs to chase the demons out. Nothing helps. Now I am afraid that Sisi is also sick. What will happen to her? I can't tell my church. They will judge me." ("Thembi" died two weeks later in a backroom of one of Johannesburg's suburbs at the age of 29. Her boyfriend arrived in time to bury her. Her daughter Sisi now lives with her grandmother and she is showing signs of being infected with HIV). ${ }^{2}$

"Lunga was so excited that morning. He was going to pre-school, face shining, clutching his sandwiches. I had told the school that he was HIV-positive. They accepted him. Things went well and Lunga thrived. Then someone broke confidentiality and told a parent that he was HIV positive. News spreads quickly. I noticed hostility when I took him to school, and then he came home crying. Parents in his class had forbidden their children to play with him. We had to remove him. It has been very hard. We know what stigma feels like and Lunga is lonely." (Louisa, foster mother of Lunga, aged 4).

"My family is very conservative. They are good people; they read their Bibles, they go to church, they pay their taxes but they never talk about sex. They simply don't understand about life today. I can't tell them the truth. They won't understand, they won't know what to do with me. I think they will judge me and I can't bear any more judgment. I am not a bad person. I just made a mistake, I was stupid and I am paying for it. The worst is not the virus but the judgment." (Annatjie, a student aged 24 , who recently discovered her status.)
\end{abstract}

Key Concepts: Stigma, feminist theology, HIV/Aids

\footnotetext{
I am indebted to Gillian Paterson and to Frank Molteno for their insights and critical feedback on an earlier draft of this paper.

"Thembi's" real name is not given to protect her daughter Sisi.
} 


\section{Introduction}

These fragments illustrate the effects of stigma on the lives of three people. There are countless such stories in South Africa where people living with HIV and Aids are all too often seen as having behaved shamefully, as being morally at fault and thus deserving punishment, or as "infectious" and therefore to be avoided.

Countering stigma is central to combating the global Aids pandemic. The complexity of the Human Immunodeficiency Virus (HIV) pales in comparison to the complexity of the social forces involved in the production and reproduction of stigma in relation to HIV and Aids. Stigma rarely acts alone. Gender stereotypes and their resultant patriarchal attitudes and practices are, for instance, part of the complex causal chain that fuels the continuing spread of HIV and Aids. This paper will focus on the nature of stigma and the challenges it presents to communities of faith $^{3}$ as they seek to deal appropriately with their role in alleviating the suffering caused by HIV and Aids.

A word of warning is, however, called for. Focussing on stigma can undermine productive debate on how to deal with HIV and Aids. If the notion of stigma becomes an umbrella concept under which all debates resort, it can divert attention from the responsibility to address the realities of transmission. Speaking only about stigma can shift the focus from the reality that infection is the result of certain types of behaviour in often complex situations. Discussions on stigma can moreover be undermined if they do not acknowledge people's legitimate fear of infection from a disease for which there is neither cure nor, for most, available treatment. It is not surprising that HIV is less stigmatized in groups that are better educated about the nature of the disease and for whom Aids has become (at least in theory) a non-fatal condition. The discussion of stigma is further complicated by the fact that HIV finds particularly fertile ground within groups that are already stigmatized. Examples are the poor, women, widows, refugees, or socially dislocated groups. Stigma feeds on pre-existing stigma, imprisoning people in situations that they are powerless to change and depriving them of their full humanity. ${ }^{4}$ Stigma is thus a complex, multi-layered and dangerous reality that demands our attention.

In this paper I explore the nature of stigma by way of fifteen interrelated observations. Before doing so I shall briefly describe my theological point of departure by explaining what I mean by an embodied theology. Thereafter, I reflect on what could constitute an appropriate response to stigma on the part of communities of faith in order to clarify and strengthen their roles in combating the Aids pandemic.

\section{Embodied Feminist Practical Theology}

I write as a Christian feminist practical theologian. This basically means two things: First, I understand feminist practical theology, or what I prefer to call feminist theology of praxis, ${ }^{5}$ as critical Christian theology that is alert to the challenges faced by women and all marginalized people in their traditions and religious institutions. Second, such theology is concerned with the tension between theory and praxis, between what we believe and what we do about what we believe. Our actions are concrete manifestations of who we are and what we believe. Thus my theological responses reflect an abiding interest in the embodied actions of communities of the faith in the broadest possible sense. Craig Dykstra and

3 The term "faith communities" is used deliberately to denote a more inclusive understanding of "church" while at the same time including the institutional churches.

I acknowledge Gillian Paterson's contributions to the views expressed in this paragraph.

5 See Denise M Ackermann, "Engaging Freedom: A Contextual Feminist Theology of Praxis". Journal of Theology for Southern Africa, Vol. 94, March 1996, 32-49. 
Dorothy Bass (2002:18) describe Christian practices as “...things Christian people do together over time to address fundamental human needs in response to and in the light of God's active presence for the life of the world". Its orientation towards "doing" means more than just "practical practices", a momentary tautology. That is why I choose the term "praxis" in preference to "practice". Patti Lather (1991:11-12) describes "praxis" as "the self-creative activity through which we make the world ... the central concept of a philosophy that did not want to remain a philosophy, a philosophy becoming practical... Praxis requires theory that is relevant to the world and nurtured by actions in it..."

Theological praxis is thus critical and self-reflective. It emphasizes the dialectical relationship between theory and praxis and introduces the essential component of ongoing critical reflection and action. In the complexity of lived experience, critical reflection on our actions feeds into revised beliefs and actions for the sake of God's truth in the world. Simply put, this emphasis on theological praxis comes from the concern that we "be doers of the word", not just hearers. To be a "doer of the word" means to be involved in active life-giving change.

My hermeneutical point of departure is that all theology should be done in service of the fulfilment of God's reign on earth. The reign of $\operatorname{God}^{6}$ brings good news to people in terms of their life situations. It speaks of justice, love, peace and wholeness, of the flourishing of righteousness and shalom. The praxis of Jesus discloses the critical and transforming vision of what it would mean if the fullness of God's presence were to be known on earth. It calls us, like Jesus, "to a radical activity of love, to a way of being in the world that deepens relation, embodies and extends community and passes on the gift of life" (Harrison 1985:18). This challenge to live by mutuality and reciprocity is never free from risk, but it is a gospel imperative.

Theological reflection and theological praxis arise within the everyday messiness of Christian lives, because what we believe and how we act, embody our efforts to meet the problems that inevitably arise when we are challenged by the values of the reign of God in our particular historical contexts. Furthermore, those who profess the Christian faith are called to be God's agents for healing this world. This means that the reign of God, as embodied in the ministry of Jesus Christ, demands the practical embodied realization of justice, love, freedom, peace and wholeness. In summary, a feminist theology of praxis studies the actions of people of faith, both inside their communities of faith and in the society in which they find themselves. This is not all. God acts, creates, sustains and redeems for the sake of all humanity. Our interest in God's activity in history and in the created world "implies that at the level of human agency, practical theology cannot be concerned exclusively with the activity of Christians or the Church" (Forrester 2000:9). Feminist theology of praxis analyses and reflects critically on the practices of people in relation to the values of God's reign on earth. It asks: "How do questions of truth relate to actions?" Or put differently: "How compassionate, caring and just are our actions?"

In the Aids pandemic communities of faith, indeed all people of faith, are facing a kairos, a moment of truth and crisis, a time for change and decisive action. ${ }^{7}$ What is there to do as hundreds die each day? What can stem the appalling increase in the death of women and its inevitable effect on the family unit? Who will care for the innumerable orphans? The questions are so daunting that our natural human reaction is to recoil or become numb,

6 Reign of God is used in preference to "Kingdom of God" as it reflects a more inclusive concept of the Godhead.

7 Kairos is a Greek word used to denote a propitious moment for decisive action, eg. see Mk. 1:15; Lk. 8:13; Rom. 13: 11-13. See also The Kairos Document: Challenge to the Church, 1986. 
and to resort to inaction since dealing with the challenges appears to be beyond our capacity. But inaction is no choice for people of faith. We are not required to perform the impossible. We are simply asked, metaphorically speaking, to be God's hands of compassion in the midst of the present crisis in our country. We can start by countering the deplorable effects of stigma, because there is no place for stigma in the fulfilment of God's reign on earth.

\section{What is Stigma?}

Originally, in classical Greece, the term "stigma" referred to a mark branded on members of outcast groups such as slaves. Today its meaning is more complex. It has no "one-sizefits-all" definition (Paterson 2003). What we understand by stigma will vary, given our historical and cultural contexts. Very broadly speaking, it is a term that marks and then excludes a person as being tainted or alien, of less value, blameworthy or to be feared as undesirably different. It leads to the rejection and exclusion of people on grounds for which they often bear no responsibility.

\section{Understanding Stigma}

It is not easy to understand stigma because it is influenced by social, cultural, ethnic, political, gender and religious factors. An awareness of the complexity of stigma is, however, the starting point for dealing more adequately with its effects. The following fifteen observations are interrelated. Representing the multi-facetted nature of stigma, they attempt to highlight a number of its aspects. Understanding is our first line of defence in the midst of this crisis that is too often fuelled by ignorance, prejudice and misunderstanding.

1. Stigma deals in lies. It refuses to see the truth of the whole human person. Stigma speaks the language of prejudice, misconception and even threat. It effectively brands "the other" as undesirable, as having, in the words of Erving Goffman (1990), a "spoiled identity".

2. Stigma thrives on silence and denial, guilt and fear. When the truth about suffering and disease cannot be named because of fear of stigmatization, reality is blanketed in silence or denied. Denial not only sacrifices the truth. It robs us of our ability to deal effectively with the virus. And thus "Thembi" died alone. Guilt and fear feed on silence and soon rob those affected and infected of their ability to engage with the virus in ways that nurture life instead of succumbing to despair and hopelessness.

3. The metaphors associated with Aids reinforce and legitimate stigmatization. For example: Aids is labelled as death, as horror, as punishment, as crime, as shame. The language in the media and popular culture often forms and encourages inaccurate images about the pandemic, particularly among those who are not properly informed. No wonder Lunga was rejected at his school.

4. Cultural taboos are common, for instance, taboos about mental illness or physical disability. HIV infection has been closely associated with sexual transmission. In cultures where open discussion on issues of human sexuality is not encouraged, sexual matters are considered suspect, even impure. The early association of HIV with homosexuality has further complicated cultural attitudes towards the virus. Later, with the heterosexual transmission of HIV, such cultures have continued to associate the virus with sexual deviance, promiscuity, and then prostitution. Cultural taboos have characterised the entire history of the epidemic and continue to function today as the most deeply rooted aspect of HIV and Aids-related stigma. 
5. Sexual stigmatization has been closely linked to gender-related stigma. Instead of understanding that HIV infection affects women more than men, due to their biological make-up and societal status, infection has typically been associated with what is considered inappropriate in terms of local gender norms. For example: Commercial sex workers are "responsible" for the spread of the disease through their "immoral" behaviour, or women generally are labelled as promiscuous and responsible for the rising rates of heterosexual transmission. Yet, contrary to these stereotypes, there is an increasing rate of infection among married women who have only one sexual partner, namely their husbands.

6. Although less clear, ethnically and culturally based stigmas related to patterns of sexual behaviour are often associated with HIV and Aids. For example: Women's infidelity in relationships is rigorously censored whereas male infidelity is either accepted or glossed over, or blacks are labelled as more promiscuous than whites and therefore deserving infection.

7. Stigma is closely related to unfair discrimination. Stigma is almost invariably the direct consequence of unfairly discriminatory attitudes and actions. Treating people differently is not necessarily unfair discrimination or stigmatization. You have to be a certain age to vote or to drive a motorcar; building restrictions apply in urban areas which do not apply in rural areas. Such differentiation is not demeaning of persons' humanity because there are sound and justifiable reasons for it. However, stigma, like unfair discrimination, is often the consequence of patterns of dominance and exclusion that are connected to the struggle for power and privilege. Consequently a stigmatized person experiences loss of dignity and acceptance and feels powerless.

8. Stigma is experienced at different levels, in society, in religious communities, in the family and individually. The introductory stories cover all these aspects of stigma and they can all lead to imposed isolation and rejection. Annatjie and "Thembi" fear being judged by their relatives and, less directly, by their communities of faith. Lunga's plight is due to ignorance coupled to stigma in society.

9. Stigma that is internalised is the most difficult to deal with since it invades a person's identity. For example: When persons are branded as unworthy or unclean because they are infected with HIV, they can internalize this lie and come to believe it as the truth about themselves. This can led to self-imposed isolation and lack of self-worth. This, I believe, is what happened to "Thembi".

10. HIV and Aids-related stigmas rarely function on their own in relation to the threat of disease. When cultural, gender, racial and sexual stigmas work together with stigmas engendered by HIV and Aids, the effects are complex and often devastating. For example: Aids is seen as either the disease of the rich or the poor, depending on one's class perspective; or Aids is a women's disease, or a disease caused by men, depending again on one's gender perspective; or Aids is a black disease or a white issue, depending on one's race perspective, and so on.

11. Stigma never arises in a social vacuum. It always has a history that influences the form it takes. It is no isolated phenomenon. Stigma functions particularly effectively at the point where culture, power and difference meet. South African history illustrates this fact clearly. Apartheid and the imposition of Afrikaner culture on this country had its roots in Afrikaner history. Afrikaner culture was deeply imbued with the notion of survival in the face of what was subsequently termed "the total onslaught". When this culture combined with political power, such power had to be maintained by stigmatizing black people as "the other". Bluntly put, stigma produces, reproduces and enforces social inequality and 
exclusion. Understanding the relationship between power, culture and difference, will show how stigma is central to the way in which the social order is managed.

12. Stigmatization can be brutal and violent or it can work with great subtlety. South Africa's first Aids martyr Gugu Dhlamini was stoned to death in 1998 for speaking out about her status. There are also countless women like "Thembi" who die quietly and alone because they believe that they deserve no better.

13. The reinforcement of stigma is not unrelated to the rapid changes taking place in the modern world. Globalization and the radical restructuring of the world economy have been characterized by, among others, accelerating processes of social exclusion, such as the growing gap between the rich and the poor of the world. Such exclusion is reinforced by pre-existing inequalities and exclusions, such as racism, sexism and religious conflict. One of the results of this kind of social exclusion is that women, children, the homeless and the jobless who increasingly bear the burden of poverty, are further stigmatized. The poor are not only poor because they are lazy but, on becoming infected, are now also immoral. Lack of basic necessities and lack of basic education, create fertile ground for the reinforcement of stigma. People are stigmatized for situations that they have no control over, and then one kind of stigma feeds into another. Understanding this is important for analysing the many layers of stigma and ultimately how they affect our ability to combat HIV and Aids.

14. There is a tragic dimension to stigma. To be a victim of stigma due to circumstances over which one has no control, like the faithful woman who is infected with HIV by her partner, is not only unjust, it is also tragic. For such a person, the effects of stigma can range from unhappiness, to severe affliction and even to a fatal calamity. Human beings aspire to a secure and meaningful existence in the face of all that imperils us. We resist a destiny that is annihilation. We long to live with understanding, respect and love. We also know and perpetuate lamentable suffering in our relationships with one another. Human suffering involves more than physical suffering. Tragically, stigmatizing "the other" alienates us from one another and, most importantly, also from ourselves. It also causes people to continue systematically to misunderstand the nature of the pandemic and its causes. Tragically this displaces much of the energy that could be used to prevent infection. As people are victimized and blamed, social divisions are reinforced when those infected are seen as being tainted and alien.

15. Stigma is not inherently part of our being. We were not born to stigmatize or to be stigmatized. Sadly, stigma is deeply ingrained in us and often we are unaware of the stigmas we perpetuate. Within the intricate web of our interdependence on one another, human beings have different kinds of agency. Not one of us is utterly without agency. Generally, we have an interest in fostering our interpersonal relationships and partaking in our social institutions. We search for a good that secures us against the perils of existence. When challenged, people can change. Social attitudes towards, for instance, gender, race, class or disease, can and do change.

\section{Stigma and the Christian Faith}

In the face of the shocking reality of stigma in our midst, what theological tools are available to people of faith, both the laity and the clergy, to deal with stigma? What should the institutional church be teaching, preaching and counselling in the present crisis? How can it shape a moral community whose common goal is the good of all? How can we be accountable to "Thembi", Lunga and Annatjie? The following suggestions on the issue of stigma are offered in order to prompt our theological reflections and to engage our praxis. 
All these suggestions emanate from my hermeneutical point of departure, namely that Christians are charged with living out the values of the reign of God. This means confronting the sinful nature of stigma squarely and then finding hope in our scriptures and our traditions for communicating God's grace, mercy and compassion in our actions in present times. Again I shall resort to fifteen observations, all interrelated, in making the case for a theological praxis that can contribute to combating HIV and Aids. All theological statements have practical implications. To act on what we believe in order that all may have life and have it abundantly, is both the challenge and the hope.

1. Stigma is sin; it is totally alien to the nature of God. Our God is a God who embraces all of creation, who so loved the world and all that is in it that God "gave his only son, so that everyone who believes in him may not perish but have eternal life" (Jh. 3:16). According to the Anglican prayer book, our God is a God "... whose nature is always to have mercy". Love, mercy and compassion as divine attributes are the very opposite of stigma which is unloving and intolerant. Our hope is vested in the very nature of our God to whom stigma is foreign and contrary to God's universal all-inclusive intention for humankind.

2. Our God is forgiving, merciful, loving and filled with compassion. Stigma is sin because it breeds judgmental attitudes that are a denial of the very nature of God. We judge who is "acceptable" and who is not, who may be included and who is to be excluded, forgetting that it is "God who executes judgment" (Ps. 75:7). We are warned repeatedly that to pass judgment on others is to pass judgment on ourselves (Rom. 2:1). Passing judgment on a sister or a brother is not worthy of a believer, for we are all subject to God's judgment. As Paul cautions the believers in Rome: "Let us therefore no longer pass judgment on one another, but resolve never to put a stumbling block or hindrance in the way of another" (Rom. 14:10). How often do we not wonder, on becoming aware of someone's positive status, how they contracted the virus? How often are these thoughts not fuelled by ignorance and tinged with judgment? Our judgmentalism is cause for critical examination, not despair. The Spirit of God is ceaselessly at work in us, purging us of attitudes that are unfit for citizens of God's reign on earth. We can and do change.

3. Stigma is sin because it denies the reality that we are created equally in the image of God (Gen. 1:27), that we are loved equally and unconditionally by God, and that we all have equal worth as bearers of the godly image. Because God ascribed dignity and equality to human beings in the work of creation, being made in the image of God speaks of the importance of equal and respectful relationships, indeed of reverence for all who bear the image, even if now only partially. Paul tells us that seeing the glory of God, we "... are being transformed into the same image from one degree of glory to another; for this comes from the Lord, the Spirit" (Rm. 3:18). When a human being is referred to as "an HIV positive", she or he becomes no more than a statistic whose identity is subsumed in such status. This is not God's ongoing creative intention for us. We can and should relish the challenge and the hope of our divine image.

4. Stigma is sin because it destroys human community by affecting human relationships negatively. Stigmatizing those of a different gender or race or class or ability, for instance, militates against community that is just, loving and compassionate. When a child cannot attend nursery school or a daughter is banished from her home because they are carrying the virus, they are not only denied their equality in the image of God, they are also denied their need for belonging. God calls us into a community of loving, mutual relationships, “...praising God and having goodwill to all people” (Ac. 2:47). Jesus tells us to "...love your neighbour as yourself" (Mk. 12:31). This injunction means very little if it is not embodied in acts of love and care. But our response to 
Christ's call is often found wanting. We find relationships of equal power and responsibility, mutual freedom and love, difficult. Despite ourselves, however, we are being constantly renewed and transformed by the life-giving power of the Holy Spirit (Rom.7:6). The making and remaking of right relationships in community is the ongoing task of the Holy Spirit and nothing we do can ultimately prevent this from being accomplished.

5. Stigma is sin because it deals in lies. Our scriptures have a great deal to say about living in truth. The psalmist asks (15:1-2): "O Lord, Who may abide in your tent? Who may dwell on your holy hill?" The answer is: "Those who walk blamelessly, and do what is right and speak truth from their heart". We are cautioned to worship God "...in spirit and in truth" (Jh. 4:24) and comforted that "...the truth will make you free" (Jh. 8:32). Stigmatizing runs counter to the work of the Spirit who, according to the Gospel, “... will guide you into all the truth..." (Jh. 14:13). Telling the truth of our stories is a powerful way of breaking the silence and stigma that permeate the HIV and Aids pandemic, particularly in a culture of denial and prevarication. We all have our stories to tell. As the truth of our stories encounters the truth of our common story - the Gospel - we are changed. Allowing this to happen liberates us to be communities who live in truth.

6. Stigma is sin because it acts covertly and it cannot bear the light. Stigma thrives in the dark. We are called to "...walk in the light of the Lord" (Is. 2:5). Jesus in the Sermon on the Mount (Mt. 5:14) tells the disciples, "You are the light of the world. A city built on a hill cannot be hid ... [so] let your light shine before others..." If we are to "...lay aside the works of darkness and put on the armour of light" (Rm. 13:12), we cannot deal with our fellow beings in whispers and innuendo. The light beckons us as Jesus promises: "I am the light of the world. Whoever follows me will never walk in darkness but will have the light of life" (Jh. 8:12).

7. Love is a distinguishing characteristic of the Reign of God, and ethically compelling for all its members. Love can never be qualified by double standards. Jesus' concern that the principle of love be maintained, prompts him to ask the questions: "Can a blind person guide a blind person? .... Why do you see the speck in your neighbour's eye, but do not notice the log in your own eye?" (Lk. 6:39, 41). Stigma is sin because is it is hypocritical and unloving. Am I aware of the log in my own eye before I look for the speck in the eye of another? Do I have a secret ranking of sin? Does "sexual" sin rate higher on my sin chart than greed, lack of love and compassion, unkindness and the abuse of power, to name but a few? Do I, like the prodigal's elder brother, need to be rescued from my "virtue"? Hypocrisy and lack of love result in worship that only honours God with our lips and not our hearts and that worships “...in human precepts as doctrines" (Mt.15:7), instead of "in spirit and in truth".

8. Humility is a Christian virtue of inestimable value. Jesus cautions his followers that "...those who exalt themselves will be humbled, and those who humble themselves will be exalted" (Lk. 14:11). In fact, Christ “...humbled himself and became obedient to the point of death" (Phil. 2:8). Stigma is sin because it breeds attitudes of superiority and arrogance. In Proverbs (15:33), "humility goes before honour". A life worthy of our calling is characterized by humility, gentleness and patience, “...bearing one another in love, making every effort to maintain the unity of the Spirit in the bond of peace" (Eph. $4: 2,3)$. Our gratitude for what God has done for us should lead us to works of compassion. Being washers of feet is no easy task. Whose feet are we stigmatizing? What did Jesus do when confronted with a stigmatized human being? Our comfort lies 
in the fact that God in Christ has forgiven us our failings, and that the Spirit is leading us into new ways, interceding for us as we pray for the healing of our beings.

9. Stigmatizing human sexuality is sinful. God created us sexual beings. Our sexual natures are God's gift to us to be enjoyed responsibly. Clearly the irresponsible exercise of our sexual natures is morally unacceptable as it leads to the abuse and exploitation of others. However, the general stigmatizing of human sexuality that is so much part of HIV and Aids-related stigma is a denial of the goodness of one of God's gifts to humanity. HIV and Aids offer the church an opportunity to reclaim and celebrate our sexual human nature in life-giving and responsible ways.

10. Stigma is sin because it closes the door on both individual and communal healing. Communities that become enmeshed in the falsehood of stigma, cease to exercise a ministry of healing. Stigma cuts off individuals from the potential for healing in their communities. The story of the Gerasene man with the unclean spirit graphically illustrates what happens when an individual is stigmatized. Living among the tombs shackled and chained, howling and bruising himself, this man is the epitome of a stigmatized life. Then a miracle happens. Jesus sees his need and heals him so that he becomes a new person "clothed and in his right mind" (Mt. 5:1-14). We all seek healing of some kind and we are all potential healers. The present pandemic presents a kairos moment to the church to be God's agent for healing on our continent in new and life-changing ways.

11. Stigma is sin because it prevents the proper functioning of the church as the Body of Christ. All receive gifts from the Holy Spirit for the "common good" of the Body (1 Cor. 12:7). The Body consists of many different members, all of whom are indispensable, and "God arranged the members in the body, each one of them, as he chose ... giving the greater honour to the inferior member" (v.18, 24). Paul follows this description of the Body with words of caution: "If one member suffers, all suffer together with it; if one member is honoured, all rejoice together with it" (v.26) and "Let all things be done for building up" (1 Cor. 14:26). Our hope for the church is founded on the fact that God gives all of us the means to accomplish the task of "building up" the Body of Christ. Stigmatizing members of the Body and thereby rendering their gifts unacceptable is to cripple the Body and to render it ineffectual. Equipped with the gifts, we can affirm and celebrate our God-given diversity, protect the weak, care for the sick and live out the Gospel of love and redemption.

12. Our scriptures have given us a language that can express the truth of the present suffering and our hope in our God. It is the language of lament (see Ackermann 2003:108-124). Given the immensity of the devastation wrought by HIV and Aids, the question is: Why are we not lamenting? The recovery of both individual and communal lament in the church can have at least three profound effects. First, effective pastoral care responds to the needs of the present. Lament spells out the present condition unequivocally by naming the painful effects of stigma and shifting the suffering from the private inner world to the outer reality of the community of faith. Lament allows tears to flow and bodies to rock in grief that provide a counter to the numbness of human suffering. Second, the public witness of a lamenting church calls attention to the suffering of the voiceless and the despair of the hopeless that challenges conditions of silence and denial. Third, HIV and Aids raise serious questions about God's power and presence in a suffering world. Where is God in this pandemic? If we stifle our questions about suffering in the world, we are tempted to settle for a God whom we dare not approach with our grief and with whom our relationship is less than truthful. However, the psalmists have shown us that God can be addressed very directly with our questions, 
our doubts and fears and, at the same time, God can be praised. Such is the power of lament that comes "out of the depths" (Ps.130:1) and which shows us an authentic and truthful way of grappling with suffering.

13. Stigma is a sin to which the Christian church has contributed significantly. We have a history of stigmatizing the Jews. We have stigmatized women, their calling and their gifts as not being of the same value as that of men. Small wonder that women's second class status in society is a powerful contributing factor to the feminization of the present pandemic. We have stigmatized the human body in a hierarchy of values by relegating it to an inferior position to the mind and the spirit, forgetting that the Incarnation is central to our faith. We have not dealt well with race, gender and class stigmas. Potential "polluters" of the social order have been made scapegoats ${ }^{8}$ who must be punished, like unmarried mothers who are seen to have violated ideals of female sexual purity, or persons infected with HIV who are refused the communion cup because they are "ritually unclean" - for which read "sexually active" (Paterson 2003). Sadly, the church cooperates in perpetuating stigma by underpinning social stigmas that are clothed in dubious moral judgments, such as pronouncing judgment on those who have Aids. However, what we have made, we can unmake. God's Spirit draws the church to renewal in order to conform to what God desires for it - a community of hope and compassion, actively practising mutual relationships that are loving and just. We cooperate in bringing this about by actively shaping moral communities that nurture the moral capacities of their members by story-telling, and by involvement in the works of justice and charity.

14. Jesus Christ is the model of what it means to live a life that demonstrates the sinfulness of stigma. He himself was stigmatized. He bore the wounds of stigma on his body. Yet his entire life, his ministry, death and resurrection offer us the great resource for countering stigma. The Gospels show us a person who has a particular concern for the suffering, the sick and the marginalized, who moves with ease across social barriers, whose compassion is so profound that it touches, heals and gives new life to those who experience stigma, disease and exclusion. His teaching brings hope to those in despair and is burdensome to those who know power. His death and resurrection hold the promise of new life for the world.

15. Most of the above points have stressed the sinful aspects of stigma. By grace, however, failure does not have the last word in the Christian life. Our hope is in Jesus Christ, whom we celebrate in the Eucharist. We remind ourselves that the origins of the Eucharist do not lie in success or triumph (Welker 2000). It was in fact instituted "....in the night that Jesus Christ was betrayed and handed over to the powers of this world". The celebration of the Eucharist makes the Reign of God present to us in the form of Christ's body broken "for us" and Christ's blood shed "for us". Christ invites us to the feast. He is both the giver of the feast and the gift itself. The communion meal offers us life-giving relationship with the Crucified One in the presence of the Risen One. Here we are offered the chance to forge mutual relationships, across all our differences. "We who are many are one body for we all partake of the one bread". This visible, unifying practice of relationship with all its potential for healing is ours. May we celebrate its potent pull away from stigma to the radical activity of loving relationships across all our differences.

8 See Mary Douglas who describes in Purity and Danger how those who are perceived as potential polluters are made scapegoats to be punished or cast out in order to perverse the "purity" of society's values. In these processes, religion plays a crucial role. See also Renee Girard (2001:154-160) for his understanding of scapegoating. 


\section{Conclusion}

In the letter attributed to James, the author cautions the faithful:

Be doers of the word, and not merely hearers who deceive themselves. For if any are hearers of the word and not doers, they are like those who look at themselves in a mirror; for they look at themselves and, on going away, immediately forget what they were like. But those who look into the perfect law, the law of liberty, and persevere, being not hearers who forget but doers who act - they will be blessed in their doing. ${ }^{9}$

An embodied feminist theology of praxis that seeks to respond to the stigma that lies at the core of the HIV and Aids pandemic, takes praxis, the "doing of the word", as the measure by which its witness, integrity and authority will be judged. The inclusive and caring witness of communities of faith in these times needs compassionate and wise women and men whose actions are marked by a repudiation of all forms of stigma, as well as by imagination, perseverance, a concern for justice, courage to put their bodies on the line and fidelity to the teachings of the One who showed us the way. Then our witness may just make a tangible difference to the lives of people like "Thembi", Lunga and Annatjie.

\section{BIBLIOGRAPHY}

Ackermann, Denise M 2003. After the Locusts: Letters from a Landscape of Faith. Grand Rapids: Eerdmans.

Douglas, Mary 1966, Purity and Danger: An Analysis of the Concepts of Pollution and Taboo. London: Routledge.

Dykstra, Craig and Bass, Dorothy C 2002. "A theological understanding of Christian practices" in Miroslav Volf and Dorothy C Bass (eds.), 2002. Practicing Theology: Beliefs and Practices in Christian Life. Grand Rapids: Eerdmans.

Forrester, Duncan B, 2000. Truthful Action: Explorations in Practical Theology. Edinburgh: T \& T Clark.

Girard, René 2001. I saw Satan fall like Lightning, tr. JW Williams. Maryknoll: Orbis Books.

Goffman, Erving 1990. Stigma: Notes on the Management of Spoiled Identity. London: Penguin.

Harrison, Beverly 1985. Making the Connections: Essay in Feminist Social Ethics. Boston: Beacon Press.

Lather, Patti 1991. Getting Smart: Feminist Research and Pedagogy with/in the Postmodern. New York: Routledge.

Link, Bruce G and Phelan, Jo C, 2001. "Conceptualizing Stigma”. Annual Review of Sociology, 27, 363-385.

Parker, Richard and Aggleton, Peter 2002. HIV and Aids-related Stigma and Discrimination: A Conceptual Framework and Implications for Action. Rio de Janeiro: ABIA.

Paterson, Gillian 2003. "Conceptualizing Stigma”, paper read at a UNAids Workshop of Theologians on HIV/Aids in Windhoek, Namibia, 8 December 2003.

Welker, Michael 2000. What Happens in Holy Communion? tr. JF Hoffmeyr. Grand Rapids: Eerdmans.

9 James 1:22-25. 